\title{
Clonal Diversity of Methicillin-resistant Staphylococcus aureus in UKM Medical Centre: Characterisation by Multilocus Sequence Typing of Different SCCmec Type Representatives
}

(Kepelbagaian Klon Staphylococcus aureus Rintang Methicillin di Pusat Perubatan UKM: Pencirian Molekul Menggunakan Penjenisan Jujukan Multilokus terhadap Wakil Jenis SCCmec yang Berlainan)

\author{
Najihan Abdul Samat Muttaqillah*, Salasawati Hussin, Hui-Min NeOH, Ainihayati Noordin, \\ ChuAn Hun Ding, ASRul ABdul WAHAB \& MD MOSTAFIZUR RAHMAN
}

\begin{abstract}
Multilocus sequence typing (MLST) has been used to characterise methicillin-resistant Staphylococcus aureus (MRSA) isolates into sequence types (STS) and together with SCCmec typing, form the clonal nomenclature for MRSA. MLST was conducted as per the standard protocol on ten out of 236 isolates collected previously from January to December 2009 representing four different SCCmec types. Relationship analysis was performed with eBURST via the MLST website. Four unlinked 'singleton' STs were detected: ST30, ST239, ST772 and ST1178. Together with SCCmec typing, five MRSA clones were identified: ST30-IV, ST239-II, ST239-III, ST772-V and ST1178-IV. Clones ST239-III and ST30-IV are already established in Malaysian hospitals and in the local community, respectively. ST772-V is an emerging clone reported previously to have a propensity to displace pre-existing predominant clones. A clone involving the predominant ST in Malaysia (ST239) with SCCmec type II is the first of its kind to be identified. MRSA clones in our centre are very diverse and clone surveillance with large sample sizes should be undertaken as collaborative efforts between local institutions to maximise detection coverage.
\end{abstract}

Keywords: Methicillin-resistant Staphylococcus aureus (MRSA); molecular characterisation; multilocus sequence typing (MLST); Staphylococcal cassette chromosome mec (SCCmec)

\section{ABSTRAK}

Penjenisan jujukan multilokus (MLST) membolehkan isolat Staphylococcus aureus rintang methicilin (MRSA) dicirikan kepada jenis-jenis jujukan (ST) tertentu. Apabila digabungkan dengan jenis jujukan SCCmec masing-masing, tatanama antarabangsa bagi klon-klon MRSA ini dapat dibentuk. Kajian MLST dijalankan mengikut protokol piawai ke atas sepuluh daripada 236 isolat MRSA terpilih yang dikumpul dari bulan Januari hingga Disember 2009 dengan setiap isolat mewakili empat jenis SCCmec yang berbeza. Hubungan antara isolat tersebut dikaji menggunakan eBURST melalui laman sesawang MLST. Empat jujukan tunggal ST yang tidak berkait telah dikenal pasti iaitu ST30, ST239, ST772 dan ST1178. Bersama-sama pencirian jujukan SCCmec masing-masing, lima klon telah dikenal pasti, iaitu ST30-IV, ST239-II, ST239-III, ST772-V dan ST1178-IV. Klon-klon ST239-III dan ST30-IV telahpun diketahui bertapak di hospitalhospital di Malaysia (ST239-III) dan juga di dalam komuniti (ST30-IV). Klon ST772-V adalah klon yang dikenal pasti sebagai klon yang baru muncul dan berkebolehan untuk menggantikan klon paling dominan sedia ada. Klon baru yang melibatkan ST paling dominan di Malaysia (ST239) dengan jujukan SCCmec jenis II telah ditemui buat kali pertama. Kami mendapati pelbagai klon MRSA dipencilkan di hospital kami. Oleh itu, kami menyarankan supaya pengawasan yang berterusan melibatkan saiz sampel yang lebih besar perlu dijalankan dengan kerjasama dari institusi tempatan yang lain bagi memaksimumkan liputan pengesanan.

Kata kunci: Kromosom kaset mec stafilokokal (SCCmec); penjenisan jujukan multilokus (MLST); pencirian molekul; Staphylococcus aureus rintang meticillin (MRSA)

\section{INTRODUCTION}

Methicillin-resistant Staphylococcus aureus (MRSA) is a major cause of nosocomial infections worldwide and is also being recovered in the community. The mecA gene, responsible for its mechanism of resistance, encodes PBP2a, an acquired penicillin-binding protein that has low affinity for methicillin and other $\beta$-lactams
(Chambers 1997). This methicillin-resistance mechanism is present in most clinical MRSA isolates, along with two other known methicillin-resistance mechanisms, namely hyperproduction of $\beta$-lactamases (McDougal \& Thornsberry 1986) and modification of normal penicillinbinding proteins (PBPs) (Tomasz et al. 1989). It is not present in methicillin-susceptible strains and is believed 
to have been acquired from a distantly related species, although not yet determined (Hiramatsu et al. 2001). It is carried on a mobile genetic element, the staphylococcal cassette chromosome mec (SCCmec), of which eleven main types (types I-XI) with their respective subtypes have been distinguished up to the present time (International Working Group on the classification of Staphylococcal Cassette Chromosome elements 2013).

MRSA isolates have been previously characterised from different hospitals or countries to identify strains that have established in several hospitals within a country, or those that have spread internationally. Multilocus sequence typing (MLST), a method developed by Martin Maiden and his colleagues at Oxford University, United Kingdom, characterises bacterial isolates unambiguously by using the sequences of internal fragments of seven housekeeping genes (Maiden et al. 1998). With the help of an online database, different sequences for each of the loci are assigned arbitrary allele numbers and the combination of the seven assigned numbers form the allelic profile, or the sequence type (ST) (Saunders \& Holmes 2007). MLST was originally developed and has been validated for $S$. aureus and provides a discriminatory method allowing related strains recovered in different countries to be readily identified and easily compared (Enright et al. 2000). In conjuction with SCCmec typing, it has provided a common international nomenclature for MRSA strains (Ito et al. 2001). MLST data may support infection control and can be used to trace nosocomial sources and transmission routes of bacterial pathogens (Ghaznavi-Rad et al.2010) and may also be used to further investigate the evolutionary and population biology of the strains (Enright et al. 2002).

Until recently, a relatively small number of major MRSA clones with epidemic potential have been reported worldwide. However, the detection of these major MRSA clones from various local centers has varied from one study to another. In our hospital, SCCmec types II, III, IV and $\mathrm{V}$ have been previously identified among 236 nonrepetitive MRSA isolates collected during the period of January to December of 2009 (Ainihayati 2010). Therefore, the objective of the present study was to characterise ten selected MRSA isolates representing members of each of the SCCmec types, by using MLST and BURST analysis (Based Upon Related Sequence Types) to determine clonal diversity of MRSA isolates in our hospital.

\section{MATERIALS AND METHODS}

\section{SAMPLING METHOD}

Four SCCmec types were previously identified among 236 MRSA isolates collected from January to December 2009; SCCmec type II (one isolate), III (223 isolates), IV (eight isolates) and V (four isolates). Ten isolates were selected for MLST from members of each of the SCCmec types by using the convenience sampling method, with the goal of sampling the same amount of isolates from each group.
Three representative isolates from each SCCmec type were selected except for the SCCmec type II group, which only contained one isolate. Whenever possible, the priority for selection was given to isolates from sterile body sites and all the selected isolates originated from different locations within the hospital.

The one and only swab specimen harbouring SCCmec type II originating from the orthopaedic clinic (MRSA 747) was selected. Majority of isolates harboured SCCmec type III, which included many from sterile sites including blood, bronchoalveolar lavage, bone, cerebrovascular fluid, pus aspirates and tissue. However, we chose blood isolates over other types of invasive isolates. Three blood isolates were randomly selected and were made sure to originate from three different locations in the hospital; the isolates chosen were MRSA 11 (High dependency ward), MRSA 598 (General intensive care unit) and MRSA 782 (Medical 3 ward). Three isolates were selected from the SCCmec type IV group comprising of a pus isolate from the Surgical 7 ward (MRSA 320), a nasopharyngeal aspirate isolate from the Paediatric 1 ward (MRSA 380) and a tracheal aspirate isolate from the Paediatric intensive care unit (MRSA 377). A blood isolate (MRSA 742) originating from the General intensive care unit was not selected to prevent the sharing of location with the previously selected MRSA 598, which was the only blood isolate from the General intensive care unit harbouring SCCmec type III. MRSA 377 and MRSA 380 were chosen at random, with both originating from two different hospital locations. The three selected isolates harbouring SCCmec type V comprised of two tissue isolates, both originating from the orthopaedic ward (MRSA $154 \&$ 347) and a swab isolate originating from the endocrine clinic (MRSA 421). MRSA 347 was selected as a replacement for the initially selected MRSA 431 (a blood isolate from the oncology ward) that was excluded due to failure to detect its 'house keeping' genes with polymerase chain reaction. Details on the ten selected isolates are summarised in Table 1.

The above selected MRSA isolates were retrieved from stock cultures in the Microbiology laboratory, which are stored at $-70^{\circ} \mathrm{C}$ on cryoprotectant beads. The beads of the respective selected MRSA were inoculated onto blood agars and were incubated overnight at $37^{\circ} \mathrm{C}$.

\section{NUCLEIC ACID EXTRACTION AND PCR FOR THE MLST ALLELES}

Five to ten single colonies of pure growth from the blood agar of each respective selected MRSA strains were picked for DNA extraction. DNA extraction was performed with the DNeasy Blood \& Tissue kit (QIAGEN, USA) according to the manufacturer's protocol. Quantification and purity of the DNA extracts were determined using the Nanodrop 2000 Spectrophotometer (Thermo Fisher Scientific, USA). PCR amplification was performed for each of the housekeeping genes for each MRSA isolate using standard primers for S. aureus MLST (Saunders \& Holmes 2007). The cycling protocol used was according to the TopTaq 
TABLE 1. Selected isolates characterised in the study

\begin{tabular}{clcll}
\hline No. & Sample ID & SCCmec type & \multicolumn{1}{c}{ Sample type } & \multicolumn{1}{c}{ Origin } \\
\hline 1 & MRSA 747 & II & Swab & Orthopaedic clinic \\
2 & MRSA 11 & III & Blood & High dependency ward \\
3 & MRSA 598 & III & Blood & General intensive care unit \\
4 & MRSA 782 & III & Blood & Medical 3 ward \\
5 & MRSA 320 & IV & Pus & Surgery 7 ward \\
6 & MRSA 377 & IV & Tracheal aspirate & Paediatric intensive care unit \\
7 & MRSA 380 & IV & Nasopharyngeal aspirate & Paediatric 1 ward \\
8 & MRSA 154 & V & Tissue & Male orthopaedic ward \\
9 & MRSA 347* & V & Tissue & Male orthopaedic ward \\
10 & MRSA 421 & V & Swab & Endocrine clinic \\
\hline
\end{tabular}

*MRSA 347 was selected as a replacement for the initially selected MRSA 431 (a blood isolate from the oncology ward) that was excluded due to failure to detect its 'house keeping' genes by polymerase chain reaction

PCR kit handbook (June 2010) (QIAGEN, USA). PCR optimisation was performed by determining optimum annealing temperatures for each of the seven housekeeping gene primers.

\section{DETECTION AND PURIFICATION OF PCR PRODUCTS}

Gel electrophoresis was performed using $1.5 \%$ agarose gel to confirm the presence and the quality of the PCR products. Purification of the PCR products was performed with the QIAquick PCR Purification kit according to the manufacturers protocol (QIAGEN, USA). Quantification and purity of the PCR purification products were also determined using the Nanodrop 2000 Spectrophotometer (Thermo Fisher Scientific, USA).

\section{DNA SEQUENCING AND ALIGNMENT}

DNA sequencing was performed for the purified PCR products according to the DNA sequencing kit protocol (Beckman Coulter, USA) on the Beckman Coulter CEQ 8000 Genetic Analysis System (Beckman Coulter, USA). For the initial sequencing reaction runs, either one of the forward or the reverse strands were sequenced for each allele. Base calling accuracy was checked with the CEQ Sequence Analysis Module in conjunction with 4 peaks software (Nucleobytes Inc., USA). Sequencing was repeated for any unsatisfactory sequences together with the sequencing of their respective complementary strands. Satisfactory DNA sequences were only used for further analysis. Sequence alignment and trimming was performed with an online analysis tool (SDSC Biology Workbench, http://workbench. sdsc.edu) using reference sequences (http://www.mlst. net). ST was determined by comparing the allelic profiles with the database at the MLST website, which is hosted at Imperial College London and is funded by the Wellcome Trust (http://saureus.mlst.net).

\section{BURST AND PHYLOGENETIC ANALYSIS}

Relationship analysis was performed with the aid of eBURST (v3) via the MLST website. The default eBURST setting was used to identify groups of related STs using the most stringent (conservative) definition, as proposed by the authors of eBURST, where all members were assigned to the same group must share identical alleles at six of the seven loci with at least one other member of the group. This group definition was used to analyse the relationship between the identified STs representative of the selected MRSA strains in this study, as well as to analyse the relationship of these STs against other STs already available in the $S$. aureus MLST database. A 'population snapshot' diagram was constructed, by changing the group definition setting in eBURST from the default value of $6 / 7$ loci to $0 / 7$ as per instructions on the website. A UPGMA dendrogram (unweighted pair group method with arithmetic mean) was also constructed via the website.

\section{RESULTS}

Four different sequence types (STs) were identified among the ten selected MRSA isolates. The sequence types identified are ST30 $(n=1)$, ST239 $(n=4)$, ST772 $(n=3)$ and ST1178 $(n=2)$. Along with their corresponding SCCmec types, five MRSA clones were identified; ST239-II $(n=1)$, ST239-III ( $n=3)$, ST30-IV $(n=1)$, ST772-V $(n=3)$ and ST1178-IV (n=2) (Table 2).

\section{RELATIONSHIP BETWEEN THE SELECTED MRSA STRAINS}

The four different STs were shown to be unlinked 'singleton STs' by using the stringent eBURST definition (i.e. they do not share alleles in at least six out of the seven loci between STs, or even five out of the seven loci using the more relaxed group definition) (eBURST Version 3). This suggests that these STs belong to distinct groups and are distantly related from each other. The relationship of these STs is illustrated in Figure 1.

RELATIONSHIP OF THE SELECTED MRSA STRAINS AGAINST OTHER S. AUREUS STRAINS IN THE MLST DATABASE

Using the default (stringent) definition of a group, analysis with eBURST shows that the four STs can be divided into three major groups, out of a total of 71 groups dividing all of the currently available STs in the $S$. aureus MLST 
TABLE 2. Allelic profiles, sequence types and MRSA clones identified

\begin{tabular}{|c|c|c|c|c|c|c|c|c|c|}
\hline MRSA ID & \multicolumn{7}{|c|}{ Allelic Profile* } & ST & Clone \\
\hline MRSA 011 & 2 & 3 & 1 & 1 & 4 & 4 & 3 & 772 & ST239-III \\
\hline MRSA 154 & 1 & 1 & 1 & 1 & 22 & 1 & 1 & 30 & ST772-V \\
\hline MRSA 320 & 2 & 2 & 2 & 2 & 6 & 3 & 2 & 772 & ST30-IV \\
\hline MRSA 347 & 1 & 1 & 1 & 1 & 22 & 1 & 1 & 1178 & ST772-V \\
\hline MRSA 380 & 1 & 181 & 1 & 4 & 12 & 1 & 10 & 772 & ST1178-IV \\
\hline MRSA 421 & 1 & 1 & 1 & 1 & 22 & 1 & 1 & 239 & ST772-V \\
\hline MRSA 598 & 2 & 3 & 1 & 1 & 4 & 4 & 3 & 239 & ST239-III \\
\hline MRSA 747 & 2 & 3 & 1 & 1 & 4 & 4 & 3 & 239 & ST239-II \\
\hline MRSA 782 & 2 & 3 & 1 & 1 & 4 & 4 & 3 & 239 & ST239-III \\
\hline
\end{tabular}

*arcC: carbamate kinase; aroE: shikimate dehydrogenase; $g l p F$ : glycerol kinase; gmk: guanylate kinase; pta: phosphate acetyltransferase; tpi: triosephosphateisomerase; yqiL: acetyl coenzyme A acetyltransferase

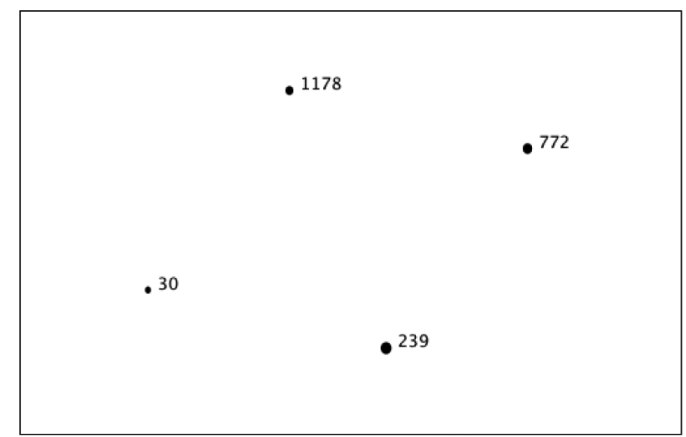

FIGURE 1. A 'Population snapshot' diagram generated by eBURST showing the unlinked relationship between the four different STs identified among the selected MRSA strains.

The areas of each of the circles indicate the prevalence of the ST in the input data

database. Each of the detected STs was examined in their respective groups, represented by figures drawn by eBURST (Figures 3, 4 \& 5, respectively). The circles in the diagram represent the predicted primary founder of the group and the subgroup founder are coloured white and grey, respectively. The areas of each of the circles indicate the prevalence of the ST in the input data.

\section{ST239}

ST239 (MRSA 11, 598, 747 \& 782) belongs to Clonal Complex 8 (CC8) within Group 1. ST239 is a single locus variant (SLV) of its subgroup founder, ST8. The predicted primary founder of Group 1 is ST5 (Figure 3).

\section{ST1178}

ST1178 (MRSA 377 \& 380) belongs to CC5 within Group 1. ST1178 is a SLV of ST5, the predicted founder of Group 1 (Figure 3). Although ST1178 and ST239 are members of the same group, the eBURST diagram shows that both occur very distantly from each other. Group 2. ST772 is a SLV of its subgroup founder, ST1.
The predicted primary founder of Group 2 though, is ST15 (Figure 4).

\section{ST30}

ST30 (MRSA 320) belongs to CC30 within Group 3. ST30 is the predicted primary founder of this group and currently has 139 SLVs (Figure 5).

\section{DISCUSSION}

Given the aforementioned sampling strategy, our study managed to demonstrate the presence of several different MRSA clones circulating in our hospital during the period of the sample collection. Of five clones identified, two clones shared SCCmec type IV (ST30-IV and ST1178IV), two were of the same sequence type but of different SCCmec types (ST239-II and ST239-III) and one was a distinct clone, ST772-V. The large differences in allelic profiles between the different sequence types were supported by eBURST analysis and the genetic distances demonstrated by the dendrogram (Figure 2); the sequence types belonged to distinct groups and were distantly related. Several studies have shown the presence of distantly related MRSA lineages (Enright et al. 2002; Fitzgerald et al. 2001; Musser \& Kapur 1992), which have 


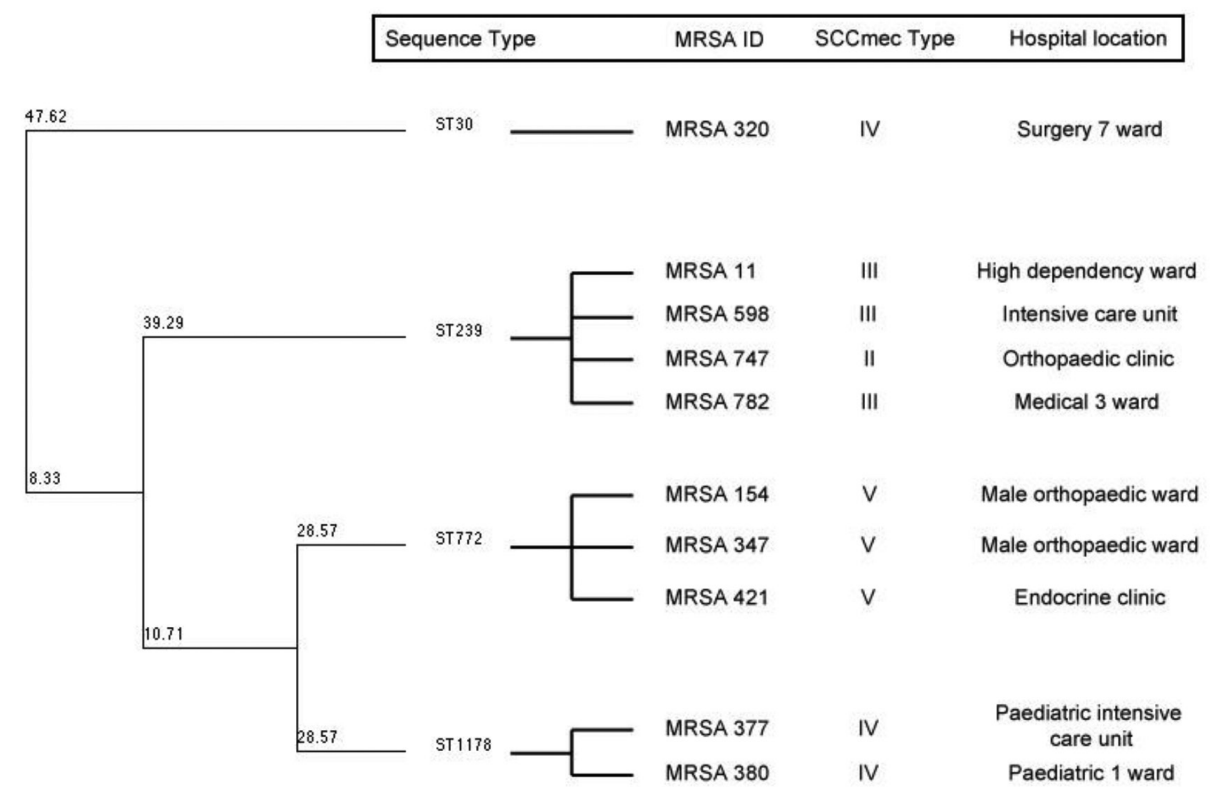

FIGURE 2. UPGMA dendrogram (via saureus.mlst.net) showing sequence types, SCCmec types and the hospital location of MRSA strains included. This dendrogram is based on the pair-wise differences in the allelic profiles. The genetic distances between the sequence types are represented as numbers above the row lines. Although significant genetic distances are demonstrated between all sequence types, ST772 and ST1178 show the most similarity compared to among other sequence types, in which their alleles differ at four of the MLST loci

diversified by the horizontal transfer of mec determinants (Enright et al. 2002).

In 2010, ST239-III/IIIA was first reported to be the predominant clone in Malaysia (Ghaznavi-rad et al. 2010; Neela at al. 2010), similar to the findings of a larger Asian study (Chongtrakool et al. 2006). ST239-III also has a history of successful dissemination in other regions, leading to a diverse array of regionally prevalent clones (Wang et al. 2012). Although prevalence was not measured, the ST239-III clone was also detected in three out of the ten selected isolates in our study. ST239 is a SLV of ST8 and as shown in Figure 3, is currently assigned by eBURST as the putative ancestral genotype of two other subgroups within CC8. ST239-III was thought to be derived from an ST8-MRSA isolate that contained SCCmec type III, via a recombinational event in the $\operatorname{arcC}$ housekeeping gene (Enright et al. 2002). Currently, ST239 has many SLVs of its own and has been quoted by authors as the putative founder of its own clonal complex, i.e. CC239 (Ko et al. 2005).

An interesting finding in our study was the detection of ST239 with SCCmec type II. This ST239-II clone has not yet been reported in previous studies. Enright et al. (2002) reported that strains with the same sequence type can harbour different SCCmec types, for example ST5 and ST8 was shown to harbor any of the SCCmec types I to IV, suggesting multiple mec introductions into $S$. aureus (Enright et al. 2002). The identification of ST239II and ST239-III in our study may demonstrate a similar phenomenon, although ST239-II may be postulated to be alternatively derived from an ST8 harbouring SCCmec type
II via recombination. This clone was recovered from a skin swab specimen from a three-week-old post-operative leg wound with serous discharge, sent from the orthopaedic clinic. Although strains harboring SCCmec type II are reported predominant in certain Asian countries like Korea and Japan, none of those strains are ST239 (Chongtrakool et al. 2006).

Besides hospital-acquired MRSA (HA-MRSA) as a well established cause of nosocomial infections, communityacquired MRSA (CA-MRSA) is also now known to cause community-acquired infections, especially skin and soft tissue infections and necrotizing pneumonia (Boyle-Vavra \& Daum 2007). However, the isolates included in our study were not categorised into HA- or CA-MRSA. Most CA-MRSA strains carry Panton-Valentine leukocidin (PVL) genes encoding a cytotoxin causing leukocyte destruction and tissue necrosis and possess a small mobile SCCmec type IV, V or VI, which are more easily transferable than the larger SCCmec types I, II and III found in HA-MRSA (Boyle-Vavra \& Daum 2007). All three ST772-V clones in our study were recovered from three different patients with carbuncle, two of which originated from the male orthopaedic ward and one from the endocrine clinic. All three isolates were also previously found to carry PVL genes (Ainihayati 2010). These isolates are likely to be CA-MRSA based on the type of SCCmec harbored, presence of PVL genes and by the site of the infection (i.e. skin and soft tissue), all of which are associated with CAMRSA, although both isolates showed resistance towards penicillin, cloxacillin, erythromycin, ciprofloxacin and gentamicin, which is an antibiogram typically seen in 


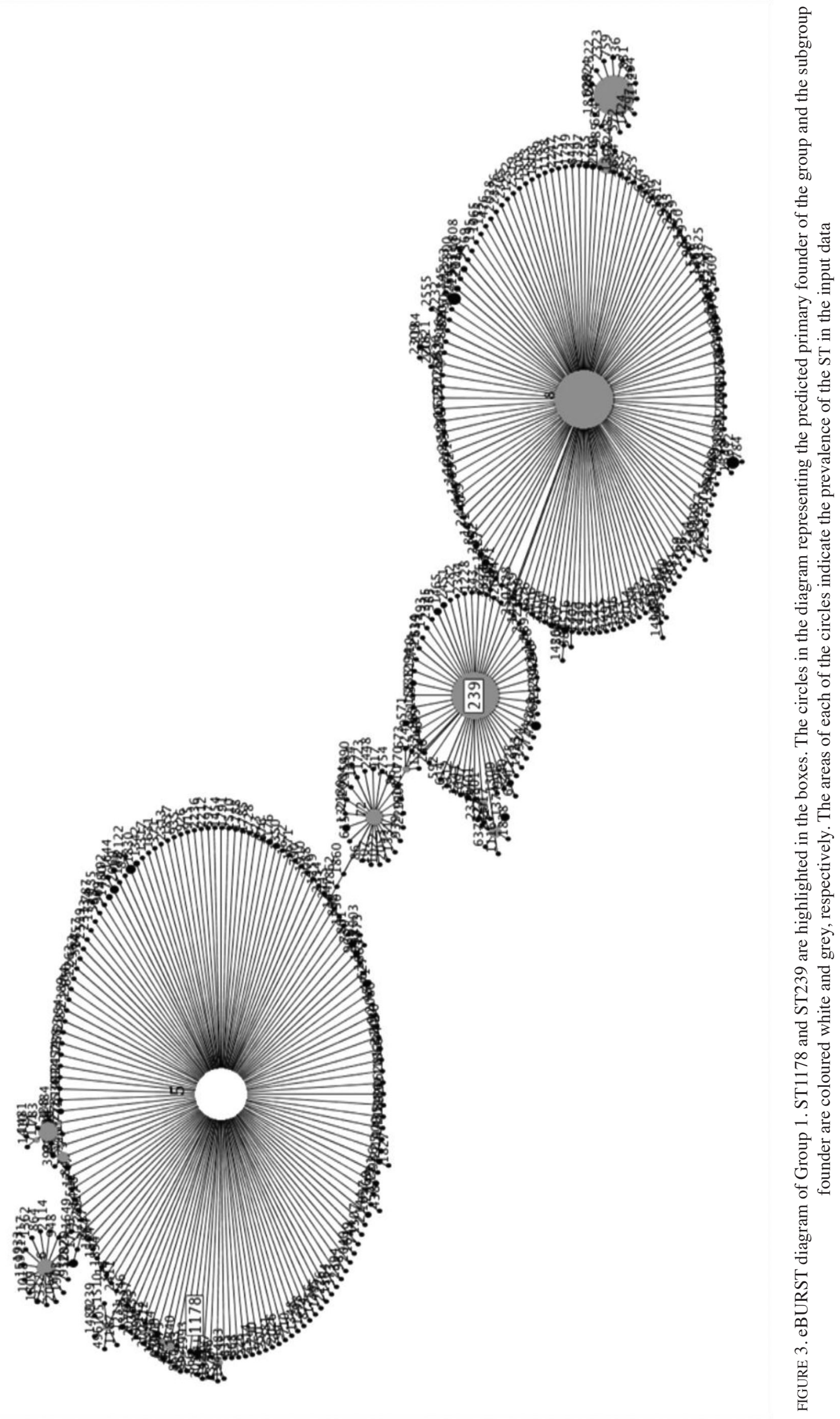




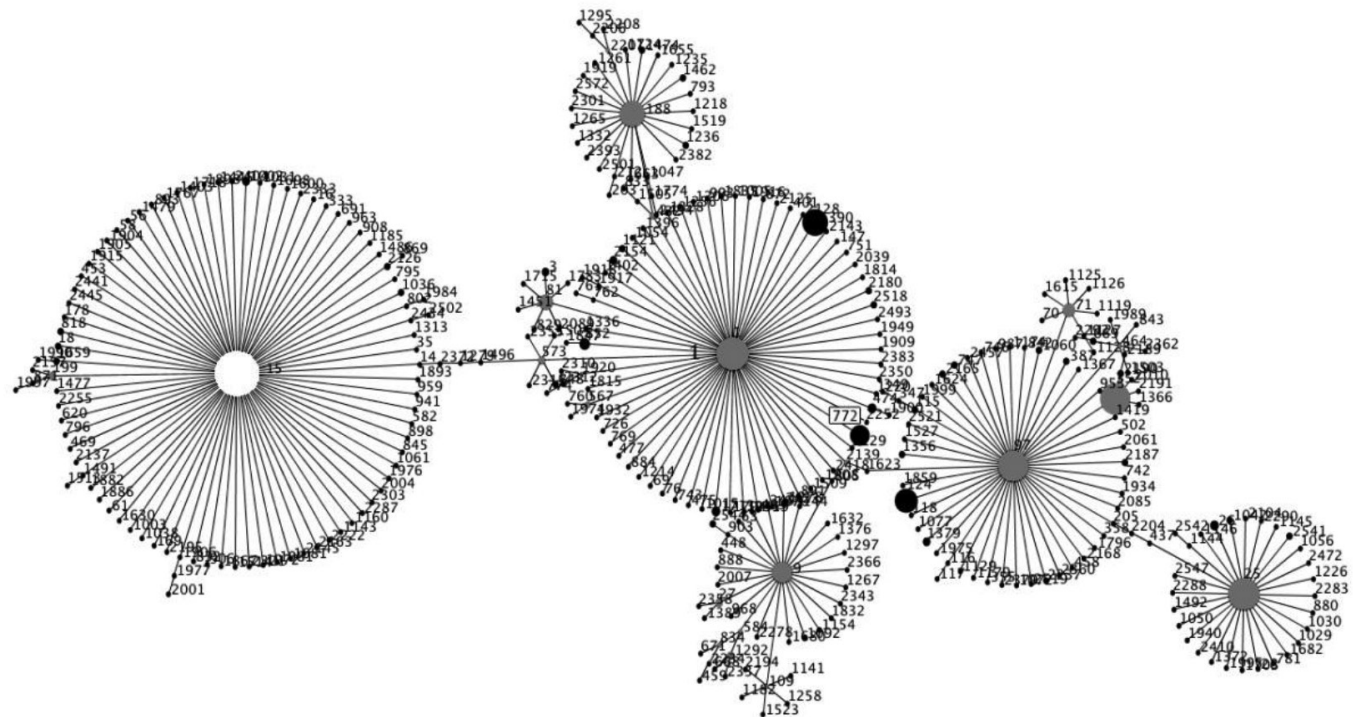

FIGURE 4. eBURST diagram of Group 2. ST772 is highlighted in the box

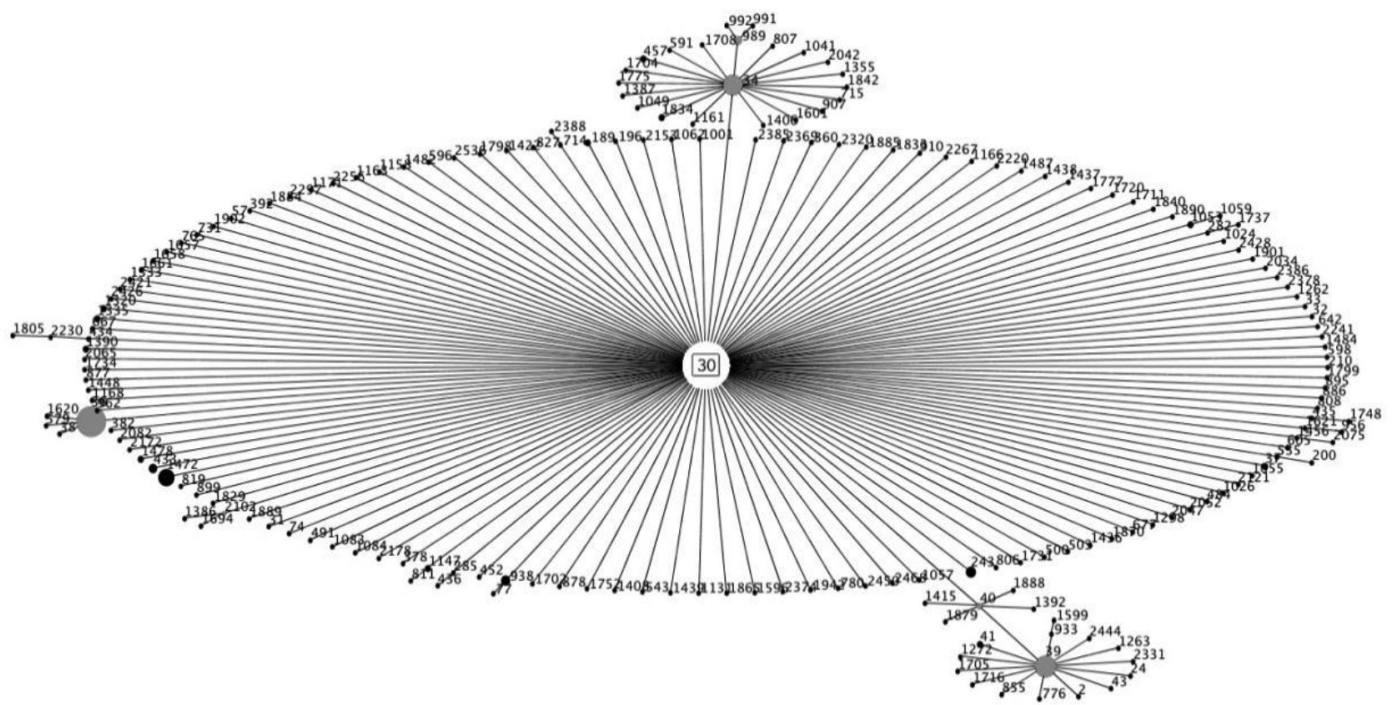

FIGURE 5. eBURST diagram of Group 3. ST30 (highlighted in the box) is the predicted primary founder of this group

HA-MRSA. Two previous local studies have also detected clones containing SCCmec type V, with one study that detected clones ST1-V and ST772-V only (Neela et al. 2010) and the other detected clones ST1-V, ST7-V and ST188-V (Ghaznavi-Rad et al. 2010). Another local study conducted by Ahmad et al. (2009) did not identify any isolates harboring SCCmec type $\mathrm{V}$ in their larger collection of isolates involving more institutions spanning across the country during the same time period. Besides the sample size, the different geographical locations in which the different studies were conducted may have also affected the number of different clones identified, as clones detected have been shown to differ from one institution to the other, even for institutions located within the same region.
Afroz et al. (2008) initially reported PVL-gene carrying methicillin-susceptible Staphylococcus aureus (MSSA) in Bangladesh that were classified into ST88, ST772 and ST573, differing from those determined for their MRSA isolates. The presence of this ST772-MSSA may suggest that the ST772-V MRSA clone may have been derived from ST772-MSSA by acquiring SCCmec type V. ST772 is a SLV of its subgroup founder ST1, belonging to clonal complex 1 (CC1) (Figure 4). MRSA ST772-V has also been reported previously in India and Malaysia (D'Souza et al. 2010; Neela et al. 2009) and subsequently in many other countries (Brennan et al. 2012). In India, ST772-V has been reported to be increasingly prevalent where it has spread into hospitals and together with ST22-IV has displaced the previously predominant nosocomial ST239- 
III clone in that region (D'Souza et al. 2010). Though not detected in our study, the clones ST22-IV and ST22IVh have also previously been identified in local studies conducted by Ahmad et al. (2009) and Ghaznavi-Rad et al. (2010). EMRSA-15 (ST22-IV), an epidemic strain first reported in England, is also known to be the predominant strain among nosocomial strains in many countries (Shore et al. 2010). ST22 is easily spread due to the small size of SCCmec type IV, giving it the potential to eventually replace the currently predominant SCCmec type III strains in Malaysian hospitals (Ahmad et al. 2009). In our study, only three out of the eight isolates containing SCCmec type IV were characterised, thus the presence of ST22 among the rest of our uncharacterised isolates containing SCCmec type IV could not be confirmed at the present time. ST30-IV was also identified in our study, which was also previously demonstrated to carry PVL genes (Ainihayati 2010). ST30-IV has also been reported to be the predominant CA-MRSA clone in Malaysia, with most of them carrying PVL genes (Ahmad et al. 2009). This MRSA clone is thought to have emerged from the introduction of SCCmec type IV into the successful ST30-MSSA clone (Enright et al. 2002). The detection of hospital-acquired ST30-IV as reported by Ahmad et al. (2009) is also a cause of concern. Another community-acquired SCCmec type IVcarrying clone (ST59) becoming an important nosocomial pathogen in hospitals has also been reported (Huang et al. 2007). On the other hand, in Japan, ST30-IV (predominant between 1979 to 1985) was shown to be replaced by ST5-II in the 1990s (Ma et al. 2006).

Two respiratory isolates from two different cases of bronchopneumonia in our study were identified as ST1178IV. One was recovered from the paediatric intensive care unit and the other from the paediatric ward. ST1178 is a SLV of ST5, which is the putative founder of clonal complex 5 (CC5) (Figure 3). At the time of writing, there was only one ST1178-IV data entry currently deposited in the MLST database. This particular clone was recovered locally from another tertiary hospital and is a clinical isolate from a diabetic foot infection. No other published information yet exists regarding this particular MRSA clone at the present time.

Due to some limitations, only ten samples were chosen randomly for this study to represent isolates from four SCCmec types. In contrast, other previous local studies have conducted sampling by way of selecting representative MRSA samples from different spa lineages or dominant spa types, as opposed to selecting SCCmec type representatives for MLST characterisation (Ghaznavi-Rad et al. 2010; Neela et al. 2010). To the best of our knowledge, our study is the first to undertake such an approach. MRSA isolates from our hospital however, have not yet undergone spa typing at the time of writing. Spa typing is useful in analysing hospital outbreaks and in identifying genetic changes that occur over a relatively short time span and more importantly has been suggested as the most suitable method to infer clonal relationships between isolates and when combined with PFGE would offer more discriminatory power for MRSA (Faria et al. 2008). Comprehensive sampling of isolates from each $\mathrm{SCC}$ mec type was done but this was challenging for isolates harbouring SCCmec type III, which had the largest number of isolates (223 isolates). In order to detect as many different clones as possible, each isolate selected originated from a different locality within the hospital, especially for isolates harbouring the same SCCmec type. The rationale for this measure was to reduce the likelihood of isolating an identical MRSA clone from different patients due to possible cross contamination or cross colonization among patients of the same ward. This may explain why clone ST772-V was isolated from both samples originating from the orthopaedic ward, as their inclusion was required as a replacement for the last isolate with this SCCmec type (MRSA 431 from the oncology ward) that had to be excluded due to technical difficulties. However, these two tissue isolates were recovered approximately two months apart from each other. Further typing by PFGE or spa typing, may be more discriminatory to further delineate the similarity between these isolates. Sampling may also be thwarted by the inter-ward movement of patients or colonised health care workers resulting in cross colonisation or cross contamination of patients across different wards when hand hygiene practices are lacking. Although additional analysis may be required, this may be the underlying reason for recovering clone ST1178-IV from both the Paediatric 1 ward and the Paediatric Intensive Care unit, which frequently see patient and staff movements from one ward to the other due to their close proximities.

\section{CONCLUSION}

Clonal diversity among the MRSA isolates included in our study was demonstrated by conducting MLST on different SCCmec type representatives, despite the limited number of isolates tested. eBURST analysis also demonstrated the distant relationships between the four detected STs among the ten isolates. The epidemic potential of the circulating clones identified calls for continuous clone surveillance and it is also important to observe changes in MRSA kinetics as elucidated from other studies. Joint efforts between different health institutions may also be necessary to maximise the detection coverage of different circulating MRSA clones in a country, as different clones may be identified from different institutions.

\section{ACKNOWLEDGEMENTS}

This study is funded by the UKMMC Fundamental grant (FF-023-2011) and the Research University Grant (UKMGUP-TKP-08-19-067). The authors would like to thank the Dean of the Faculty of Medicine and the Head of the Department of Medical Microbiology and Immunology, Universiti Kebangsaan Malaysia for their cooperation and support to conduct this study. 


\section{REFERENCES}

Afroz, S., Kobayashi, N., Nagashima, S., Alam, M.M., Hossain, A.B., Rahman, M.A., Islam, M.R., Lutfor, A.B., Muazzam, N., Khan, M.A., Paul, S.K., Shamsuzzaman, A.K., Mahmud, M.C., Musa,A.K.\& Hossain, M.A. 2008. Genetic characterization of Staphylococcus aureus isolates carrying Panton-Valentine leukocidin genes in Bangladesh. Jpn. J. Infect. Dis. 61(5): 393-396.

Ahmad, N., Ruzan, I.N., Abd Ghani, M.K., Hussin, A., Nawi, S., Aziz, M.N., Maning, N. \& Eow, V.L. 2009. Characteristics of community- and hospital-acquired methicillin-resistant Staphylococcus aureus strains carrying SCCmec type IV isolated in Malaysia. J.Med. Microbiol. 58: 1213-1218.

Ainihayati Noordin. 2010. Personal Communication.

Boyle-Vavra, S. \& Daum, R.S. 2007. Community-acquired methicillin-resistant Staphylococcus aureus: The role of Panton-Valentine leukocidin. Lab. Invest. 87(1): 3-9.

Brennan, G.I., Shore, A.C., Corcoran, S., Tecklenborg, S., Coleman, D.C. \& O'Connell, B. 2012. Emergence of hospitaland community-associated Panton-Valentine leukocidin positive methicillin-resistant Staphylococcus aureus genotype ST772-MRSA-V in Ireland and detailed investigation of a ST772-MRSA-V cluster in a neonatal intensive care unit. $J$. Clin. Microbiol. 50(3): 841-847.

Chambers, H.F. 1997. Methicillin resistance in staphylococci: Molecular and biochemical basis and clinical implications. Clin. Microbiol. Rev. 10(4): 781-791.

Chongtrakool, P., Ito, T., Ma, X.X., Kondo, Y., Trakulsomboon, S., Tiensasitorn, C., Jamklang, M., Chavalit, T., Song, J.H. \& Hiramatsu, K. 2006. Staphylococcal cassette chromosome mec (SCCmec) typing of methicillin-resistant Staphylococcus aureus strains isolated in 11 Asian countries: A proposal for a new nomenclature for SCCmec elements. Antimicrob. Agents Chemother. 50(3): 1001-1012.

D'Souza, N., Rodrigues, C. \& Mehta, A. 2010. Molecular characterization of methicillin-resistant Staphylococcus aureus with emergence of epidemic clones of sequence type (ST) 22 and ST772 in Mumbai, India. J. Clin. Microbiol. 48(5): 1806-1811

Enright, M.C., Day, N.P., Davies, C.E., Peacock, S.J. \& Spratt, B.G. 2000. Multilocus sequence typing for characterization of methicillin-resistant and methicillin-susceptible clones of Staphylococcus aureus.J.Clin. Microbiol. 38(3): 1008-1015.

Enright, M.C., Robinson, D.A., Randle, G., Feil, E.J., Grundmann, H. \& Spratt, B.G. 2002. The evolutionary history of methicillin-resistant Staphylococcus aureus (MRSA). Proc. Natl. Acad.Sci. USA 99(11): 7687-7692.

Faria, N.A., Carrico, J.A., Oliveira, D.C., Ramirez, M. \& de Lencastre, M. 2008. Analysis of typing methods for epidemiological surveillance of both methicillin-resistant and methicillin-susceptible Staphylococcus aureus strains. J. Clin. Microbiol. 46(1): 136-144.

Fitzgerald, J.R., Sturdevant, D.E., Mackie, S.M., Gill, S.R. \& Musser, J.M. 2001. Evolutionary genomics of Staphylococcus aureus: Insights into the origin of methicillin-resistant strains and the toxic shock syndrome epidemic. Proc. Natl. Acad. Sci. USA. 98(15): 8821-8826.

Ghaznavi-Rad, E., Nor Shamsudin, M., Sekawi, Z., Khoon, L.Y., Aziz, M.N., Hamat, R.A., Othman, N., Chong, P.P., van Belkum, A., Ghasemzadeh-Moghaddam, H. \& Neela, V. 2010. Predominance and emergence of clones of hospitalacquired methicillin-resistant Staphylococcus aureus in Malaysia. J. Clin. Microbiol. 48(3): 867-872.
Hiramatsu, K.,Cui,L., Kuroda, M. \& Ito,T. 2001. The emergence and evolution of methicillin-resistant Staphylococcus aureus. Trends Microbiol. 9(10): 486-493.

Huang, Y.H., Tseng, S.P., Hu, J.M., Tsai, J.C., Hsueh, P.R. \& Teng, L.J. 2007. Clonal spread of SCCmec type IV methicillinresistant Staphylococcus aureus between community and hospital. Clin. Microbiol. Infect. 13(7): 717-724.

International Working Group on the Classification of Staphylococcal Cassette Chromosome (SCC) Elements. 2013. Currently identified SCCmec types in S. aureus strains. http://www.sccmec.org/Pages/SCC_TypesEN.html.Accessed on 23 December 2012.

Ito, T., Katayama, Y., Asada, K., Mori, N., Tsutsumimoto, K., Tiensasitorn, C. \& Hiramatsu, K. 2001. Structural comparison of three types of staphylococcal cassette chromosome mec integrated in the chromosome in methicillin-resistant Staphylococcus aureus. Antimicrob. Agents Chemother. 45(5): 1323-1336.

Ko, K.S., Lee, J.Y., Suh, J.Y., Oh, W.S., Peck, K.R., Lee, N.Y. \& Song, J.H. 2005. Distribution of major genotypes among methicillin-resistant Staphylococcus aureus clones in Asian countries. J. Clin. Microbiol. 43(1): 421-426.

Ma, X.X., Ito, T., Chongtrakool, P. \& Hiramatsu, K. 2006. Predominance of clones carrying Panton-Valentine leukocidin genes among methicillin-resistant Staphylococcus aureus strains isolated in Japanese hospitals from 1979 to 1985. J. Clin. Microbiol. 44(12): 4515-4527.

Maiden, M.C., Bygraves, J.A., Feil, E., Morelli, G., Russell, J.E., Urwin, R., Zhang, Q., Zhou, J., Zurth, K., Caugant, D.A., Feavers, I.M.,Achtman, M. \& Spratt, B.G. 1998. Multilocus sequence typing: A portable approach to the identification of clones within populations of pathogenic microorganisms. Proc. Natl. Acad. Sci. USA 95(6): 3140-3145.

McDougal, L.K. \& Thornsberry, C. 1986. The role of betalactamase in staphylococcal resistance to penicillinaseresistant penicillins and cephalosporins. J. Clin. Microbiol. 23(5): 832-839.

Musser, J.M. \& Kapur, V. 1992. Clonal analysis of methicillinresistant Staphylococcus aureus strains from intercontinental sources: Association of the mec gene with divergent phylogenetic lineages implies dissemination by horizontal transfer and recombination. J. Clin. Microbiol. 30(8): 20582063.

Neela, V., Ghasemzadeh Moghaddam, H., van Belkum, A., Horst-Kreft, D., Mariana, N.S. \& Ghaznavi-Rad, E. 2010. First report on methicillin-resistant Staphylococcus aureus of Spa type t037, sequence type 239, SCCmec type III/IIIA in Malaysia.Eur.J.Clin. Microbiol.Infect. Dis. 29(1): 115-117.

Neela, V., Ehsanollah, G.R., Zamberi, S., val Belkum, A \& Mariana, N.S. 2009. Prevalence of Panton-Valentine leukocidin genes among carriage and invasive Staphylococcus aureus isolates in Malaysia. Int. J. Infect. Dis. 13(3): e131-e132.

Saunders, N.A. \& Holmes, A. 2007. Multilocus sequence typing (MLST) of Staphylococcus aureus. Methods Mol. Biol.391: 71-85.

Shore, A.C., Rossney, A.S., Kinnevey, P.M., Brennan, O.M., Creamer, E., Sherlock, O., Dolan, A., Cunney, R., Sullivan, D.J., Goering, R.V., Humphreys, H. \& Coleman, D.C. 2010 Enhanced discrimination of highly clonal ST22-methicillinresistant Staphylococcus aureus IV isolates achieved by combining spa, dru, and pulsed-field gel electrophoresis typing data. J. Clin. Microbiol. 48(5): 1839-1852. 
Tomasz, A., Drugeon, H.B., de Lencastre, H.M., Jabes, D. McDougoull, L. \& Billie, J. 1989. New mechanism for methicillin resistance in Staphylococcus aureus: Clinical isolates that lack the PBP2a gene and contain normal penicillin-binding proteins with modified penicillin-binding capacity. Antimicrob. Agents Chemother. 33(11): 1869-1874.

Wang, S.H., Khan, Y., Hines, L., Mediavilla, J.R., Zhang, L., Chen, L., Hoet, A., Bannerman, T., Pancholi, P., Robinson, D.A., Kreiswirth, B.N., Stevenson, K.B. \& Prevention Epicenter Program of the Centers for Disease Control and Prevention. 2012. Methicillin-resistant Staphylococcus aureus sequence type 239-III, Ohio, USA, 2007-2009. Emerg. Infect. Dis. 18(10): 1557-1565.

Najihan Abdul Samat Muttaqillah*, Salasawati Hussin, Ainihayati Noordin, Chuan Hun Ding, Asrul Abdul Wahab \& Md Mostafizur Rahman

Department of Medical Microbiology and Immunology Universiti Kebangsaan Malaysia Medical Centre

Universiti Kebangsaan Malaysia

56000 Kuala Lumpur, Wilayah Persekutuan

Malaysia
Hui-min Neoh

UKM Medical Molecular Biology Institute

Universiti Kebangsaan Malaysia Medical Centre

Universiti Kebangsaan Malaysia

56000 Kuala Lumpur, Wilayah Persekutuan

Malaysia

*Corresponding author; email: muttaqillah@ppukm.ukm.edu.my

Received: 22 May 2014

Accepted: 15 May 2015 